\title{
Short-term Vegetation Responses to Fire in the Upper Sonoran Desert
}

\author{
GEORGE H. CAVE AND DUNCAN T. PATTEN
}

\begin{abstract}
Annual and perennial plant vegetation was sampled following a controlled burn (1981) and a wildfire (1980) in the Upper Sonoran Desert near Phoenix, Ariz. Perennial plant composition 1 year after controlled burning included $32 \%$ shoot survivors, $30 \%$ sprouters, and $38 \%$ seeders, mostly brittle bush (Encelia farinosa ${ }^{\prime}$ ). Several invader species, stickweed (Stephanomeria exigua) and four o'clock (Mirabilis bigelovii) were important seeders, indicating that there may be postfire successional communities in the Upper Sonoran Desert. Most cacti were fire killed or died eventually from fire damage. Total annual plant density decreased (69\%) while biomass increased significantly (131\%) on burned areas. Red brome (Bromus rubens) was essentially eliminated 1 year after fire while schismus (Schismus arabicus) and Indian wheat (Plantago spp.) increased in both density and biomass. Fire appears to enhance rangeland productivity in the Upper Sonoran Desert.
\end{abstract}

Deserts of the southwestern United States have been increasingly impacted by man and as a result may be rapidly deteriorating. One such impact is an increase in fire occurrence on desert or semidesert recreation and rangeland areas. Desert fire ecology research, however, is lacking compared to available data from other ecosystems (Wells et al. 1979 and Lotan et al. 1981). This deficiency may be attributed to Shreve's (1925 and 1951) statements characterizing the desert responses to fire disturbance as a direct and relatively rapid recovery back to the climax community. Muller (1940) and Whittaker (1975) have presented similar hypotheses for general disturbances in the desert. In addition, Humphrey (1963 and 1974) stated that fires have never been a factor of much importance and that their occurrence in the Upper Sonoran Desert is rare. All of these statements have undoubtedly discouraged researchers from studying desert fires. Fire can, however, occur relatively frequently in the Upper Sonoran Desert during dry seasons that follow moist winters (USDA 1980).

Fires in southern Arizona desert grassland near Tucson, where fires can occur more frequently than in most desert areas, have been studied by Humphrey (1949), Humphrey and Everson (1951), Reynolds and Bohning (1956), Humphrey (1963), Cable (1967), White (1969), and Martin (1983). These studies reported vegetation responses to fire and investigated the use of fire as a tool for controlling undesirable species on grazing land.

Fire ecology in the Upper Sonoran Desert of central Arizona has only been recently studied (Whysong and Heisler 1978, Rogers and Steele 1980, McLaughlin and Bowers 1982, Patten and Cave 1984). This desert is floristically different from the southern Arizona desert grasslands, and fire recovery data are not comparable. Other recent studies have been conducted in southern Arizona semidesert

\footnotetext{
Authors are graduate assistant, Department of Botany/Microbiology, and director of The Center for Envirnnmental Studies and professor of botany, Arizona State University, Tempe 85287

The authors are indebted to the staff at Tonto National Forest, in particular to James Kimble and James Brown. In addition, W.D. Clark, M. Knox, S. Link, R. Mays, D. Robinson, G. Ruffner, T. Thomas, S. Workman, and especially Stan Smith deserve special recognition for their various contributions and assistance. We would also like to thank Jack Dieterich and Leonard DeBano from the U.S. Forest Service, Rocky Mountain Forest and Range Experiment Station, Arizona State University, Tempe.

Manuscript accepted March 7, 1984.
}

(Wright 1980), the western Colorado Desert (O'Leary and Minnich 1981), the Chihuahuan Desert (Ahlstrand 1982), and the Great Basin Desert (Rogers 1980). All these efforts reflect contemporary interests in re-evaluating and contributing to knowledge of fire ecology in North American deserts. To the extent that large portions of the Upper Sonoran Desert are used as rangeland, the present study is of particular interest because of the potential stimulatory effect fire has on rangeland productivity.

This study was designed to examine short-term effects of fire on both annual and perennial plant communities in the Upper Sonoran Desert through the use of controlled burning and study of an adjacent wildfire area. Specific objectives were: (1) to characterize 1- and 2-year postfire, herbaceous plant communities (annuals) with respect to changes in density and biomass in both open/shrub (small shrubs plus interspaces) and shaded (small trees) microhabitats; and (2) to examine the density and survival/recovery strategies of 1- and 2-year postfire tree, shrub, and cactus plant communities.

\section{Methods}

The study site was located in Bulldog Canyon, a desert canyon near Phoenix, Ariz., in the Tonto National Forest at $33^{\circ} 15^{\prime} \mathrm{N}$ and $111^{\circ} 33^{\prime} \mathrm{W}$ with an elevation of $450 \mathrm{~m}$. Three fire treatment sites were studied: (1) a wildfire area in which 84 ha burned on 26 May 1980 ; (2) 1 unburned hectare used for the controlled burn site and located adjacent to the wildfire site; and, (3) another adjacent, unburned hectare selected as a no fire control site. The controlled burn site was burned on 12 June 1981 by fire crews from Tonto National Forest.

Vegetation in the canyon was typical of the Upper Sonoran Desert in central Arizona and is characterized by the palo verdecactus (mostly Opuntial and Carnegiea gigantea)-shrub (mostly Ambrosia deltoidea) association (Shreve 1951). These perennial plants occupy about one-third of total ground cover. Perennial grasses are rare in this portion of the Upland Desert, but herbaceous annual forbs and grasses are abundant after winter and heavy summer rains.

Precipitation data were from Stewart Mountain Weather Station operated by the National Oceanic and Atmospheric Administration and located approximately $5 \mathrm{~km}\left(33^{\circ} 34^{\prime} \mathrm{N}\right.$ and $\left.111^{\circ} 32^{\prime} \mathrm{W}\right)$ from the study site.

\section{Herbaceous Plants}

Herbaceous plant data were collected during 2-5 April 1981 and 13-17 March 1982, during each year's peak annual plant growth period. Plants were sampled on the no fire, controlled burn, and wildfire sites using randomly located $20 \times 20 \mathrm{~cm}$ plots within both shaded and open/shrub areas. This segregation was designed to permit separate comparisons for annual plant species that grow primarily in shaded microhabitats (Tiedemann et al. 1971 and Patten 1978), and to distinguish fire recovery effects in shaded areas where annual plant growth can frequently be much greater than in partially shaded or unshaded areas created by low shrubs

\footnotetext{
INomenclature follows Kearney and Peebles (1960) and Lehr (1978).
} 
and open interspaces. Twenty plots were located in each area except for open/shrub areas on the no fire site which had 14 plots during 1981 sampling. For each species within the plots, density and above-ground biomass were calculated, the latter by harvesting above-ground growth and drying for $48 \mathrm{hrs}$ at $60^{\circ} \mathrm{C}$ before weighing.

Table 1. Mean herbaceous (annual) plant density (no. plants $/ \mathrm{m}^{2}$ ) and biomass $\left(\mathrm{gm} / \mathrm{m}^{2}\right.$ ) in 1981 and 1982 for two microhabitats (open/shrub and shade) within three fire treatment areas (no fire, wildfire 1980, and control burn 1981). Means followed by the same letter (a or b for 1981 comparisons among the three treatments and $x$ or $y$ for 1982 comparisons) are not significantly different $(P<0.05)$ according to Dunn's multiple comparison test. Where no significance is given, data were absent for comparison or were grouped (e.g., others).

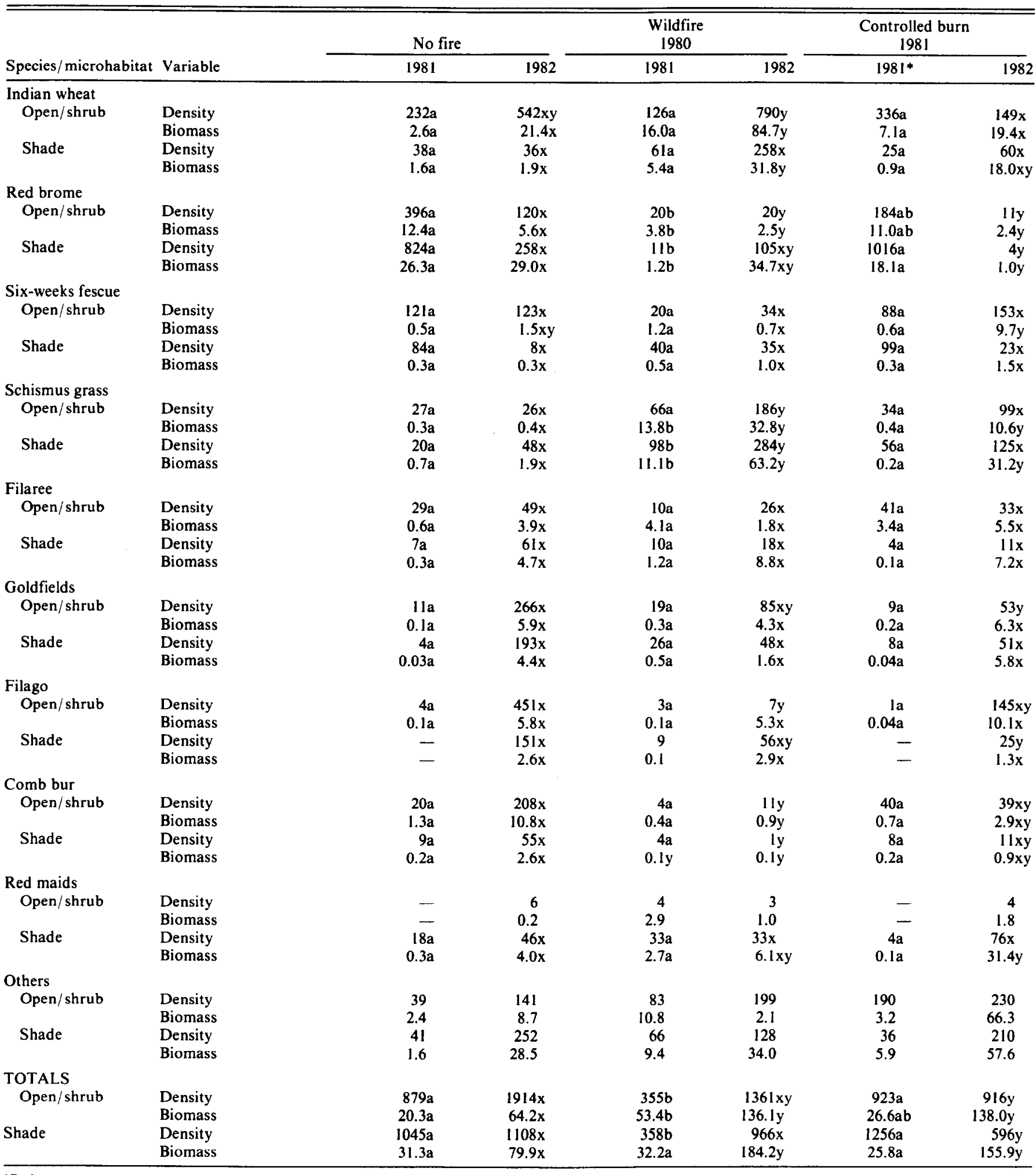

* Preburn measurements. 
Shaded area herbaceous plant plots were located under randomly selected palo verde (Cercidium microphyllum) and ironwood (Olneya tesota) trees at 4 aspects (N, S, E, and W) from the stem at one-half canopy radius. Open/shrub area plots were located at random points not associated with tree canopies but including both open interspaces or low shrubs. Density and biomass values for the 9 most abundant annual plant species were analyzed among the 3 collection sites at each sampling time using the Kruskal-Wallis procedure (Dixon 1977) followed by Dunn's test (Hollander and Wolfe 1973). Separate comparisons were performed for shaded and open/shrub area plant data. Values for all species were then totaled and analyzed in the same manner.

\section{Woody Perennials and Cacti}

Tree, shrub and cactus plant data were collected on permanent 4 $\times 8$-m quadrats (Cox 1974) for both the controlled burn $(n=23)$ and wildfire $(n=10)$ sites. Plant densities were censused 3 times on the controlled burn site (27 May 1981 for preburn values, and 16 June 1981 and 17 March 1982 for postfire values), and 2 times on the wildfire site (23 June 1981 for 1 year after fire and 17 March 1982 for 2 years after fire). The 5 most important species (based on importance values) on the controlled burn site were analyzed using Kruskal-Wallis procedure and Dunn's test in order to test for significant differences among sampling times. In addition, for all postfire measurements, the survival and/or recovery strategy of each plant was classified and recorded as a seedling, sprout, or surviving adult.

The use of the word significant in statistical analysis and discussion of data indicates a probability level $<0.05$, unless otherwise stated.

\section{Results and Discussion}

Precipitation at Stewart Mountain for the winter growing season (December through March) was $275 \mathrm{~mm}$ in 1979-80, $90 \mathrm{~mm}$ in $1980-81$, and $154 \mathrm{~mm}$ in 1981-82. These represent 216,71 , and $121 \%$ of the 1951-1980 30-year annual average of $127 \mathrm{~mm}$ for the 4-month period. As a result of above-normal precipitation, prefire standing crop of herbaceous annual plants prior to the 1980 wildfire was lush. The wildfire was probably more intense than the 1981 controlled burn; however, the 2 sites appeared similar enough after burning to justify intersite comparisons. Lower than normal 1981 precipitation did not produce good winter and spring annual plant growth for ground cover, but this biomass was supplemented by remaining litter on unburned areas from the 1979-80 wet winter. Good germination and growth conditions for most desert species did occur in 1982 following above-normal winter rainfall.

\section{Herbaceous Plants}

Mean density and biomass values for the 9 abundant annual plant species are presented in Table 1. Species listed as "Others" include plants from the following genera: Plagiobothrys, Amsinckia, Cryptantha, Astragalus, Poa, Eriophyllum, Calandrinia, Lotus, Lupinus, Dichelostemma, Eschsholzia, Platystemon, Euphorbia, Silene, Pholistoma, Bowlesia, Orthocarpus, Androsace, Daucus, Phacelia, Parietaria, Eucrypta, Chenopodium, Rafinesquia, Linathus, and Lepidium.

Before the controlled burn in 1981, all herbaceous plant means calculated for the no fire and controlled burn (1981* - Table 1) sites were not significantly different. This supports the assumption that comparisons between the 1982 no fire and controlled burn sites will accurately reflect fire-induced changes. Since the 1980 wildfire site was located adjacent to the other 2 sites, its prefire status was presumed to have been sufficiently similar to allow for statistical comparisons among all sites. No comparisons were calculated between 1981 and 1982 data because differing temperature and rainfall patterns between years affects each desert growing season's annual plant productivity and species composition (Patten 1978, Webb et al. 1978).

In 1981, of the 9 species listed in Table 1, only red brome (Bromus rubens) and schismus (Schismus arabicus) grasses responded significantly to the 1980 wildfire. In open/shrub areas, red brome density on the wildfire site was reduced by 95 and $89 \%$ while biomass declined by 69 and $65 \%$ when compared to the no fire and controlled burn (preburn conditions) site. Similar trends were recorded for red brome in shaded areas. In contrast to red brome, schismus grass density increased significantly in both open/shrub and shaded areas 1 year after the wildfire.

Red brome continued to show a reduction for the second year after the 1980 wildfire and repeated the first-year reduction patterns on the controlled burn. After 2 years, intermediate values for brome in the shade indicated a gradual recovery. Horton and Kraebel (1955) also found brome grasses in southern California to be greatly reduced in the first postfire year. Studies by Keeley et al. (1981) suggest that reductions may be caused by low seed survival during fire or low soil seed reserves at the time of the fire.

Horton and Kraebel (1955) postulated that peak populations of brome grasses require several postfire years for either seed dispersal into burncd areas and/or on site build-up from pioneering postfire plants. Since red brome remained significantly reduced in open/shrub areas 2 years after burning in the present study, it appears that at least 3 to 4 years will be necessary for full red brome recovery in the desert. However, in the more mesic, shaded areas where seeds may have survived better because of light surface burning and low fire temperatures below the thick insulation (Pat

Table 2. Mean tree, shrub, and cactus densities (no. plants/ha) at three sampling times on the 12 June 1981 controlled burn site ( $\mathrm{n}=23$ ) and at two
sampling times on the adjacent 26 May 1980 wildfire site $(n=10)$. Means for the controlled burn site followed by the same letter (a or b) are not
significantly different $(P<0.05)$ according to Dunn's multiple comparison test. Only the five most important species were analyzed. There were no
significant differences between 1981 and 1982 data on the wildfire site.

\begin{tabular}{|c|c|c|c|c|c|}
\hline \multirow[b]{2}{*}{ Species } & \multicolumn{3}{|c|}{ Controlled burn 1981} & \multicolumn{2}{|c|}{ Wildfire 1980} \\
\hline & 27 May $1981^{*}$ & 16 June 1981 & 17 March 1982 & 23 June 1981 & 17 March 1982 \\
\hline Bursage & $6275 a$ & $1141 \mathrm{~b}$ & $1141 \mathrm{~b}$ & 3590 & 3844 \\
\hline Cholla cactus & $450 a$ & $191 \mathrm{~b}$ & $177 \mathrm{~b}$ & 280 & 157 \\
\hline Foothill palo verde & $203 a$ & $150 \mathrm{a}$ & $55 \mathrm{a}$ & - & - \\
\hline Jojoba & $143 a$ & $142 \mathrm{a}$ & $68 \mathrm{a}$ & 31 & 31 \\
\hline Brittle bush & $82 a$ & $14 a$ & $707 a$ & $63 a$ & 81 \\
\hline Ironwood & 32 & 27 & 27 & 31 & 31 \\
\hline Desert mallow & 27 & -1 & 14 & 31 & 31 \\
\hline Barrel cactus & 14 & 14 & 14 & - & - \\
\hline Saguaro & 14 & 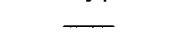 & 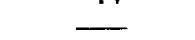 & - & $\ldots$ \\
\hline Four o'clock & $\ldots$ & $\ldots$ & 109 & - & - \\
\hline Stickweed & - & 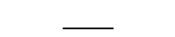 & 95 & 310 & 313 \\
\hline Others & 149 & 177 & 69 & 31 & 31 \\
\hline TOTALS & 7607 & 1856 & 2476 & 4367 & 4516 \\
\hline
\end{tabular}


ten and Cave 1984), red brome density and biomass attained intermediate values within 2 years after burning.

In 1982, schismus continued to respond to fire with higher densities in open/shrub areas on both the controlled burn and wildfire sites (Table 1). Schismus biomass production also significantly increased manyfold on the 2 burn sites with increases in the shade greater than in the open. Apparently schismus grass seeds survive fire well, and subsequent germination, which appears to be stimulated by fire, allows this species to achieve higher density and biomass in the postfire herbaceous plant community.

Of the remaining 7 genera and species in Table 1, 3-goldfields (Lasthenia californica); filago (Filago arizonica and $F$. californica; and comb bur (Pectocarya recurvata and $P$. playtcarpa)-were reduced by fire. One-filaree (Erodium cicutarium)-showed no significant response; and 3-red maids(Calandrinia ciliata), sixweeks fescue (Vulpia octoflora), and Indian wheat (Plantago insularis and $\boldsymbol{P}$. purshii)-were stimulated by fire. Goldfields was reduced in density primarily in the open/shrub areas. Filago, which normally grows best in intermediate shade locations, was reduced in all conditions; however, it recovered more rapidly in the shade. The absence of filago in the shade in 1981 was probably a result of year-to-year variations in temperature and precipitation because it had a uniform presence in 1982 . Comb bur had lower densities and biomass in 1982 on the wildfire site than on the controlled burn site, indicating that the probable higher intensity of the 1980 wildfire reduced these species more than the controlled burn.

Of the herbaceous species that showed a positive response to fire, red maids increased in biomass primarily in the shade, but these increases diminished by the second year. The density of red maids was not significantly affected by fire. Indian wheat, a characteristic annual in open and semishaded areas in the desert, had significantly greater biomass (ca. $300 \%$ ) on the wildfire site than on the controlled burn or no fire sites in 1982. Its response in shade was high biomass values on the 2-year-old wildfire, intermediate values on the 1-year-old controlled burn, and lowest values on the no fire site, indicating a continued increase for a few years following fire. Six-weeks fescue increased dramatically in biomass $(547 \%)$ in the open/shrub areas 1 year after fire as measured on the controlled burn and then showed a reduction after 2 years measured on the wildfire site. Densities of this species showed little change. There were no significant changes in density or biomass of six-weeks fescue in the shade, although the pattern of first-year increase with a subsequent decline occurred.

In open/shrub areas during 1981 there were significant reductions in total herbaceous plant density (ca. 60\%) and increases $(163 \%)$ in biomass on the wildfire site when compared to the no fire site (Table 1). In 1982, herbaceous plant density in open/shrub areas was also reduced 1 year after controlled burning, but the 2-year wildfire site had intermediate values that were significantly different from either the no fire or controlled burn sites. In contrast, biomass was significantly greater on both fire treatment sites when compared to the no fire site.

Similar trends in total herbaceous plant density and biomass were recorded in shaded areas (Table 1). In this microhabitat, however, increased biomass (ca. 13\%) in 1981 on the wildfire site was not significant, but the reduction in density (ca. 69\%) was. In 1982 , a $46 \%$ reduction in herbaceous plant density on the controlled burn site was observed when compared to the no fire site. The 1980 wildfire site density was intermediate again. Biomass was greater on both fire treatment sites (controlled burn $95 \%$ and wildfire $131 \%$ ) when compared to the no fire site. These data indicate significant reductions in herbaceous plant density 1 year after fire. During the second postfire year herbaceous plant density achieved intermediate status between prefire and 1 year after fire. Aboveground biomass, on the other hand, increased significantly after fire. This increase was attenuated into the second postfire year for both shaded and open/shrub areas. Since biomass increased after fire, while density decreased, the average biomass per plant must have also increased after fire. This demonstrates the ability of desert annuals to respond positively to fire, initiating a solid recovery with increased biomass within 2 years.

The reduction in total herbaceous plant density was primarily a result of low red brome density on burned sites, while increases from schismus, Indian wheat, and red maids contributed to total increases in biomass. These results for herbaceous plant responses parallel findings for southern Arizona desert grasslands (Reynolds and Bohning 1956, and Cable 1967), the Chihuahuan Desert (Ahlstrand 1982), North American annual plant grasslands (Daubenmire 1968) and California chaparral (Christensen and Muller 1975).

\section{Woody Perennials and Cacti}

Tree, shrub and cactus responses are presented in Table 2. Density of the most abundant species, bursage, was reduced by $82 \%$ after the controlled burn. However, numerous seedlings had established on the adjacent wildfire burn site (ca. $78 \%$ of all bursage individuals) producing intermediate density values. McLaughlin and Bowers (1982) also recorded very high mortality rates for bursage after fire in the Sonoran Desert in south-central Arizona.

Cholla cactus (Opuntia acanthocarpa, 95\%; O. fulgida, 3\%; and O. bigelovii, $2 \%$ ) densities were reduced by about $58 \%$ immediately after controlled burning. In addition to initial reductions in density, these cacti declined further between the 2 postfire sampling times on both sites (Tablc 2), indicating that some cacti, not killed at the time of or shortly after fire, die eventually from latent heat damage to epidermal and mesophyll tissue. Visual observations of cacti in later sampling dates verified this result. No seedlings or sprouts were recorded for any cactus species; postfire cacti consist entirely of adults that survive fire with little or no injury. Barrel cactus (Ferocactus acanthodes) was unaffected by controlled burning while all saguaro cacti (Carnegiea gigantea) found within sampling quadrats were killed by fire. However, other larger saguaros, that were not sampled on the site, managed to survive, although scorched epidermis may permit invasion of fungi or other lethal vectors. Observations of burned sites indicate that small saguaros less than about 2-4 $\mathrm{m}$ in height do not survive when large fuel quantities are present near the base, while larger individuals with extensive corky bases usually survive with limited damage. On the wildfire site, all cacti except chollas had died within a year after fire. As noted earlier, this site probably burned more intensely thereby consuming more of the perennial plant community than on the controlled burn site. Results for cacti presented in this study differ slightly from McLaughlin and Bowers (1982) as they did not record any cactus mortality subsequent to initial postfire measurements. Rogers and Steele (1980), however, recorded observations in the Upper Sonoran Descrt similar to this study as did Bunting et al. (1980) for cacti in Texas mixed prairie.

The 2 tree species, palo verde and ironwood, had different responses to fire. Density of ironwood was virtually unaffected by fire while palo verde underwent an initial $26 \%$ reduction followed by an overall $73 \%$ reduction 9 months after fire (Table 2 -controlled burn site). These results are supported by high ironwood densities on the wildfire site where palo verde was essentially eliminated after fire. The decline in palo verde density (Table 2 ) indicates that this species also suffered from heat damage (probably to the cambium) during the fire, taking several months to eventually kill trees or portions of their crowns. In comparison, ironwood with thicker bark is rather resistant to fire and/or heat damage. Twenty-two percent of palo verdes that survived had basal or aerial sprouting within 9 months after fire; ironwood was present only as surviving adults. These results parallel findings by Rogers and Steele (1980), and McLaughlin and Bowers (1982).

Density of the economically important plant, jojoba (Simmondsia chinensis), was substantially reduced within 9 months after the controlled burn (Table 2). On the wildfire site, jojoba was less abundant than on the controlled burn site, but its density remained 
unchanged between sampling times. Jojoba is an active postfire sprouter in the desert in that $60 \%$ of postfire jojoba plants on the controlled burn site and $100 \%$ on the wildfire site were sprouting.

Brittle bush (Encelia farinosa) underwent an initial $83 \%$ reduction in density, but within 9 months it had increased to $762 \%$ above preburn status on the controlled burn site (Table 2). This was caused by very successful seed germination and subsequent seedling establishment on the controlled burn site. Similarly, desert mallow (Sphaeralcea ambigua) appears to be greatly reduced or eliminated by fire and shows recovery or reinvasion within a year.

Two species that were not recorded in the prefire vegetation appeared after fire: four o'clock (Mirabilis bigelovii) and stickweed (Stephanomeria exigua) (Table 2). Densities of these species were large enough to indicate that they may be initiating an invasion of the site. Both species were present only as seedlings and neither species was recorded by Rogers and Steele (1980), or McLaughlin and Bowers (1982) on other Upper Sonoran Desert burn locations. Rogers and Steele (1980), however, recorded two genera (Cassia and Castilleja) not normally found in the climax community growing at their study area.

Total tree, shrub and cactus density was reduced by $76 \%$ immediately after the controlled burn (Table 2). Nine months after the fire, density for these growth forms had increased slightly because of extensive brittle bush seedling establishment. Averages from recovery and/or survival strategy data indicate that on 16 June $1981,98 \%$ of all perennials were adults surviving the controlled burn while on 17 March 1982,9 months after burning, the same site was composed of $38 \%$ seedlings, $30 \%$ sprouts, and $32 \%$ adults. At the latter sampling time, the wildfire site consisted of $48 \%$ seedlings, $13 \%$ sprouts, and $52 \%$ adults indicating that seedling establishment is more important than sprouting for postfire desert recovery as noted by Rogers and Steele (1980).

\section{Conclusions}

The herbaceous plant community responds rapidly to fire with an overall reduction in plant density and increase in above-ground biomass. Soil fertility increases commonly observed after burning in other ecosystems also occur in the desert (Whysong and Heisler 1978) and at least partially account for the reported increases in above-ground biomass after fire.

Although red brome seeds (with large awns) apparently do not survive fire well in the desert, schismus seeds (without awns) do; subsequently, postfire schismus growth is extensive. If herbaceous plant biomass remains high for several more postfire years, it is reasonable to conclude that burning may stimulate desert rangeland productivity. Where grazing allotments are involved, this suggestion has very important ramifications for desert rangeland management, especially in light of current trends to convert desert land into more profitable uses. Therefore, any efforts to use prescribed burning should remain experimental until a long-term data base exists on which to make more reliable predictions.

Desert perennials also respond quickly to fire with large amounts of seed germination and aerial or basal sprouting. Due to the short-term nature of this study, data presented primarily record immediate fire loss and the initial recovery phase.

The appearance of two nonclimax species (four o'clock and stickweed) suggest that in the Upper Sonoran Desert ecosystem, specific postfire successional plant communities may exist, or at the very least, specific postfire successional species occur. Results from Rogers and Steele (1980) support this hypothesis as they also recorded nonclimax postfire species. They postulated that it may take $\mathbf{2 0}$ years for plant density and decades for species composition to return to prefire status. These hypotheses seem tenable in light of the marked vegetation changes recorded here during the first two postfire years, especially the reduction in such long-lived species as saguaro.

If partial postfire successional plant communities do exist in the desert, then it is reasonable to infer that present plant distribution patterns may have been more influenced by fire than originally hypothesized by Shreve (1925 and 1951) and Humphrey (1963 and 1974). Desert fire ecology therefore requires additional study in order to determine the full extent of the effects of fire on the desert ecosystem.

\section{Literature Cited}

Ahlstrand, G.M. 1982. Response of Chihuahuan Desert mountain scrub vegetation to burning. J. Range Manage. 35:62-65.

Bunting, S.C., H.A. Wright, and L.F. Neuenschwander. 1980. Long-term effects of fire on cactus in the southern mixed prairie of Texas. J. Range Manage. 33:85-88.

Cable, D.R. 1967. Fire effects on semidesert grasses and shrubs. J. Range Manage. 20:170-176.

Christensen, N.L., and C.H. Muller. 1975. Effects of fire on factors controlling plant growth in Adenostoma chaparral. Ecol. Monogr. 45:29-55.

Cox, G.W. 1974. Laboratory manual of general ecology. Wm. C. Brown Co., Dubuque, la.

Daubenmire, R. 1968. Ecology of fire in grasslands. In: Advan. Ecol. Res. 5:209-266

Dixon, W.J. 1977. BMDP - Biomedical Computer Programs P-Series. Univ. California Press, Berkeley.

Hollander, M., and D.A. Wolfe. 1973. Nonparametric statistical methods. John Wiley and Sons, New York.

Horton, J.S., and C.J. Kraebel. 1955. Development of vegetation after fire in the chamise chaparral of southern California. Ecology 36:244-262.

Humphrey, R.R. 1949. Fire as a means of controlling velvet mesquite. burroweed, and cholla on southern Arizona ranges. J. Range Manage. 2:175-182

Humphrey, R.R. 1963. The role of fire in the desert and semidesert grassland areas of Arizona. Proc. Tall Timbers Fire Conference, Tallahassee, Fla.

Humphrey, R.R. 1974. Fire in the deserts and desert grassland areas of North America. p. 365-401. In: T.T. Kozlowski and C.E. Ahlgren (eds.), Fire and Ecosystems, Acad. Press, New York.

Humphrey, R.R., and A.C. Everson. 1951. Effect of fire on mixed grass shrub range in southern Arizona. J. Range Manage. 4:264-266.

Kearney, T.H., and R.H. Peebles. 1960. Arizona Flora. Univ. California Press, Berkeley.

Keeley, S.C., J.E. Keeley, S.M. Hutchinson, and A.W. Johnson. 1981. Postfire succession of the herbaceous flora in southern California chaparral. Ecology 62:1608-1621.

Lehr, H.J. 1978. A catalogue of the flora of Arizona. Desert Botanical Garden, Phoenix, Ariz.

Lotan, J.E., M.E. Alexander, S.F. Arno, R.E. French, O.G. Langdon, R.M. Loomis, R.A. Norum, R.C. Rothermel, W.C. Schmidt, and J.V. Wagtendonk. 1981. Effects of fire on flora. USDA Forest Serv. Gen. Tech. Rep. WO-16. Forest Serv. National Fire Effects Workshop, Denver, Colo.

Martin, S.C. 1983. Responses of semidesert grasses and shrubs to fall burning. J. Range Manage. 36:604-610.

McLaughlin, S.P., and J.W. Bowers. 1982. Effects of wildfire on a Sonoran Desert plant community. Ecology 63:246-248.

Muller, C.H. 1940. Plant succession in the Larrea-Flourensia climax. Ecology $21: 206-212$.

O'Leary, J.F., and R.A. Minnich. 1981. Postfire recovery of creosote bush scrub vegetation in the western Colorado Desert. Madroño 2:61-66.

Patten, D.T. 1978. Productivity and production efficiency of an Upper Sonoran Desert ephemeral community. Amer. J. Bot. 65:891-895.

Patten, D.T., and G.H. Cave. 1984. Fire temperatures and physical characteristics of a controlled burn in the Upper Sonoran Desert. J. Range Manage. 37:277-280.

Reynolds, H.G., and J.W. Bohning. 1956. Effects of burning of a desert grass shrub range in southern Arizona. Ecology 37:769-777.

Rogers, C.F. 1980. Photographic documentation of vegetation change in the Great Basin Desert. Ph.D. Diss., Univ. Utah, Salt Lake City.

Rogers, G.F., and J. Steele. 1980. Sonoran Desert fire ecology. USDA Forest Serv. Gen. Tech. Rep. RM-81.

Shreve, F. 1925. Ecological aspects of the deserts of California. Ecology 6:93-103.

Shreve, F. 1951. Vegetation and flora of the Sonoran Desert. Vol. I. Vegetation. Carnegie Inst., Washington, D.C. Publ. 591:1-192.

Tiedemann, A.R., J.O. Klemmedson, and P.R. Ogden. 1971. Response of four perennial southwestern grasses to shade. J. Range Manage. $24: 442-447$ 
U.S. Department of Agriculture. 1980. Tonto National Forest Annual Fire Reprt. Phoenix, Ariz.

Webb, W., S. Szarek, W. Lauenroth, R. Kinerson, and M. Smith. 1978. Primary production and water use in native forest. grassland and desert ecosystems. Ecology 59:1239-1247.

Wells, C.G., R.E. Campbell, L.F. DeBano, C.E. Lewis, R.L. Fredrikson, E.C. Franklin, R.C. Froelich, and P.H. Dunn. 1979. Effects of fire on soil. USDA Forest Serv, Gen. Tech. Rep. WO-7.

White, L.D. 1969. Effects of wild fire on several desert grassland shrub species. J. Range Manage. 22:284-285.
Whittaker, R.H. 1975. Communities and Ecosystems. 2nd. ed. MacMillan, New York.

Whysong, G.L., and M.H. Heisler. 1978. Nitrogen levels of soil and vegetation in the Upper Sonoran Desert as affected by fire. Proc. 1st Internat. Range Cong., Soc. Range Manage., Denver, Colo.

Wright, H.A. 1980. The role and use of fire in the semidesert grass-shrub type. USDA Forest Serv. Gen. Tech. Rep. INT-85, Intermountain Forest and Range Exp. Sta,, Ogden, Utah. 